\title{
Plant regeneration of Aloysia citrolodora L. from shoot tip explants
}

\author{
Neveen H. El-Sadat ${ }^{1}$, Ayman I. EL-D. Soliman ${ }^{1}$ and O.A.H. El-Zeiny ${ }^{2}$ \\ ${ }^{I}$ Medicinal Plants (Plant Tissue Culture) Dept., National Organization for Drug Control and \\ Research (NODCAR), Giza, Egypt. \\ ${ }^{2}$ Vegetable Research Dept., Horticultural Research Institute, Agriculture Research Center, Dokki, \\ Giza, Egypt
}

Received: 11 July 2020 / Accepted 05 Sept. 2020 / Publication date: 25 Sept. 2020

\begin{abstract}
Lemon verbena (Aloysia citrolodora) has a high medicinal value, so this study was conducted to set up a protocol for micropropagation from shoot tip explant when it cultured on four different salt strength (full, $3 / 4,1 / 2$ and $1 / 4$ ) of MS and WPM media without any growth regulators. Shoot tip explant growth was achieved on MS full strength medium. Shoot proliferation was obtained at relatively high frequency when mini shoots were cultured on MS medium supplemented with BA at $(0.4,0.8,1.6$ and $3.2 \mathrm{mg} / \mathrm{L}$ ). Best results were obtained on MS medium supplemented with $3.2 \mathrm{mg} / \mathrm{L} \mathrm{BA}$. The medium containing $0.5 \mathrm{mg} / \mathrm{L}$ IBA plus $1.0 \mathrm{~g} / \mathrm{L}$ A.C was the effective medium for roots formation. In vitro plantlets which produced were successfully transferred to the acclimatization medium Peat moss + Vermiculite $(1: 1 \mathrm{v} / \mathrm{v})$, and the percentage of the survival plantlets was $91 \%$ under mist condition in the greenhouse of the tissue culture lab.
\end{abstract}

Keywords: MS medium, WPM, BA, IBA, Concentrations, Activated charcoal, Acclimatization

\section{Introduction}

Lemon verbena (Aloysia citrolodora) is a wide spread medicinal plant with lemon aromatic scent belonging to family verbenaceae, it is a semi-medicinal shrub in Argentina and Latin America (Akeroyd, 2000). Lemon verbena is cultivated for its the lemon aroma emitted from leaves, the most economical part in the plant is the leaves, it is used as a lemony taste in tea, salads, milk, jellies and ice creams (Hanna et al., 2011; Beemnet et al., 2013). The leaves used as digestive, carminative due to the carvone content and its precursor limonene which it is the main components of Aloysia's essential oil (Cabanillas et al., 2003; Figueiredo et al., 2004). The high quality essential oil of Aloysia's used in perfumery, because the essence of lemon verbena is one of most expensive and rare essential oils in the market (Rezig et al., 2019). The extracted aromatic oil from leaves used in industries food, soft drink and cosmetics as flavoring and fragrance. Aloysia's essential oil has antioxidant, antibacterial and anti-fungal properties due to its chemical composition (Hanna et al., 2011), the most portion of the plant is the leaves which can add for the lemon-flavored taste in tea, food dressing, milky product, and candies. Ali et al. (2011), mentioned that it is difficult to obtain seeds due to Egyptian climate; common multiplication practice is vegetative propagation through stem cutting. However, stem cutting practices is not efficient enough to produce mass production required because it is not easy through seeds, since it need to maintain a very high soil temperature and even cutting are tricky as. Using in vitro propagation technique is very important to have a large amount of disease-free plants, true-to type healthy stock plantlets in a short period of time (Sharaf El-Din et al., 2011; El-Banna, 2018). Most of reported research were using direct organogenesis of A. citridora, which reported by Sharaf El-Din et al. (2011).

The recent study aimed to establish a methodology for direct in vitro propagation of lemon verbena to have a high-number of shoot initiation and regeneration of the plant directly.

\section{Material and Methods}

That work was down in the Tissue Culture Laboratory of Applied Research Center of Medicinal Plants and Natural Products during the period from 2017-2018.

Corresponding Author: A.I. EL-D. Soliman, Medicinal Plants (Plant Tissue Culture) Dept., National Organization for Drug Control and Research (NODCAR), Giza, Egypt. E-mail: madyan.ayman@yahoo.com 


\section{Plant material and culture conditions: \\ 1.1. Source of explant:}

The shoot tip explants of Lemon verbena (Aloysia citrolodora) were collected from the young shoots (one - week old) from young grown plants in pots (4 month old) from the greenhouse of tissue culture lap. The explant was thoroughly washed with running tap water to remove all dust and microorganisms. Then, the explants was sterilized in $70 \%$ ethanol for a minute, and finally with $0.1 \%$ $\mathrm{Hg} \mathrm{Cl}_{2}$ for 1 to 2 min and washed 4 to 5 times with distilled sterile water, after that the shoot tip explants was cut to about $(0.2-0.5 \mathrm{~cm})$ in length while, the node explants was cut into $(0.4-0.6 \mathrm{~cm})$. Both of explants were cultured inside the Laminar Air Flow Hood on the basal nutrient media contained macro and micro elements according to MS medium (Murashige \& Skoog, 1962). The $\mathrm{pH}$ of the media adjusted at $5.7+0.1$ before addition of the agar. The media distributed into culture jars each jar contained $50 \mathrm{ml}$ and sterilized by autoclaving at $121^{\circ} \mathrm{C}$ for $20 \mathrm{~min}$. Cultures were incubated at $25+2^{\circ} \mathrm{C}$ and sufficient fluorescent light of $3000 \mathrm{Lux}$ for $16 \mathrm{hr}$. photoperiod provided by cool white fluorescent lamps.

\subsection{Establishment stage}

The shoot tips section were placed on MS medium and WPM (woody plant medium, Lloyd \& McCown, 1980) without any growth regulators at four different salt strength (full strength, $3 / 4,1 / 2$ and $1 / 4$ strength).

\section{Shoots formation.}

For shoot formation excised mini shoots $(3.0 \mathrm{~cm}$ in long) which resulted from the starting stage was cultured on MS medium with different concentration $(0.4,0.8,1.6$ and $3.2 \mathrm{mg} / \mathrm{L})$ of benzyl adenine (BA) to study their effects on growth and development of plants. Shoot formation (\%) and number of shoots per culture was recorded after four weeks from culturing.

\section{Root formation:}

The obtained shoots which resulted from the multiplication stage was cultured on the rooting medium containing MS supplemented with IBA at, $(0.5,1.0$ and $2.0 \mathrm{mg} / \mathrm{L})$ plus $1.0 \mathrm{~g} / \mathrm{L}$ Activated Charcoal for each. Rooting \%, root number/explant and root length $(\mathrm{cm})$ were recorded after four weeks on rooting medium.

Each treatment was consisted of three replicates and each replicate was resembled in 12 jars during, starting stage, shoot formation and root formation.

\section{Acclimatization:}

The complete plantlets were washed with current tap water, and disinfected by immersion in fungicide solution $1.0 \mathrm{mg} / \mathrm{L}$ (Previcur N, 72.2\%) and the transferred to plastic pots $(7.5 \times 10.5 \mathrm{~cm}$ ) containing one of the different media for hardening as following:

1. Peat moss + Vermiculite (1:1).

2. Vermiculite + washed sand $(1: 1)$.

3. Peat moss + Vermiculite + washed sand $(1: 1: 1)$.

Each treatment was consisted of 20 pots. Each pot was contained one plantlet. Pots were then transferred to the greenhouse and covered with polyethylene sheets to maintain high relative humidity around plants. In addition, spraying with water under the plastic sheets carried out daily, while the irrigation took place 3 times a week. Surviving plants were recorded after 4 weeks from transplanting.

\section{Statistical analysis}

The designer of the experiments was completely randomized design. The data were subjected to the statistical analysis of variance procedure and all the means compared by using the L.S.D. method at $5 \%$ level of significance according to Snedicor \& Cochran (1980). 


\section{Results and Discussion}

\section{Establishment stage:}

The shoot tip explants of Aloysia citrolodora which placed on MS full strength medium were healthy and grew vigorously than the shoot tip which placed on each of $3 / 4,1 / 2$ and $1 / 4$ MS medium. However, full strength, $3 / 4,1 / 2$ and $1 / 4$ WPM did not have any response or growth. Shoot tip possessed the highest number of shoots on MS full strength also the shoot length was significantly affected by MS full strength. The highest shoot number $(2.93$ shoot/explant), the highest shoot length $(9.59 \mathrm{~cm})$ and the highest average of leaves number (10.58 leaves/explant) was obtained on MS medium as shown in table (1) and fig (1). That result was in response with Dahab et al., (2005) they noticed that highest number of shoot per explant were recorded on the medium with full salt strength and it is significantly higher than on any others salt strengths media, MS full strength medium gives the best response number of shoots from the newly buds, compared with half and quarter strength media

Table 1: The effect of MS and WPM media salt strength on the growth and development of Aloysia citrolodora shoot tip explants during the establishment stage.

\begin{tabular}{lccc}
\hline Treatments & Shoot number/explant & Shoot length $(\mathbf{c m})$ & Leaves number/explant \\
\hline MS & 2.93 & $9.59 \mathrm{~cm}$ & 10.58 \\
$3 / 4$ MS & 2.63 & 7.98 & 8.21 \\
$1 / 2$ MS & 1.42 & 5.34 & 6.00 \\
$1 / 4$ MS & 1.00 & 2.30 & 4.00 \\
WPM & 0.0 & 0.0 & 0.0 \\
3/4 WPM & 0.0 & 0.0 & 0.0 \\
$1 / 2$ WPM & 0.0 & 0.0 & 0.0 \\
$1 / 4$ WPM & 0.0 & 0.0 & 0.0 \\
L.S.D 5\% & 0.05 & 0.92 & 1.1 \\
\hline
\end{tabular}

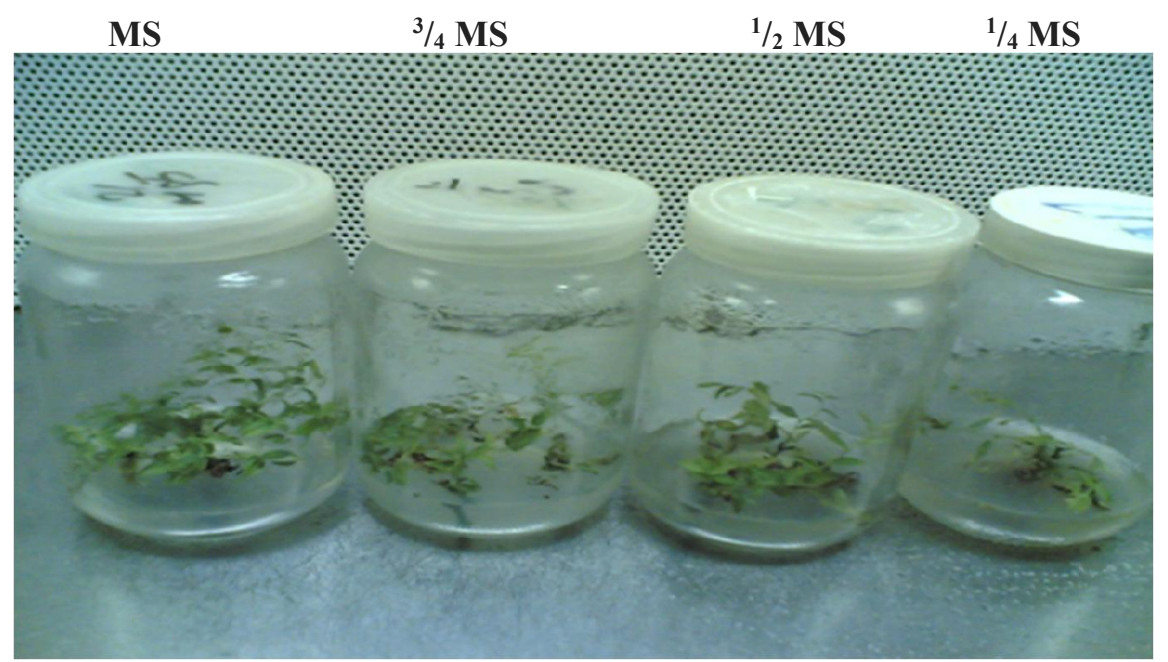

Fig. 1: Shoot induction on different salt strength of MS medium.

\section{Shoot formation:}

Addition of BA at the concentrations from $(0.4-3.2 \mathrm{mg} / \mathrm{L})$ increased number of shoots, the shoot length and number of leaves. MS medium supplemented with $3.2 \mathrm{mg} / \mathrm{L}$ BA give the highest number of shoots $(4.5$ per shoot $)$ and gave a highest shoot length $(12.7 \mathrm{~cm})$ and highest number of leaves (14.0) leaves/shoots as shown in table (2).

A significant shoot multiplications rate was obtained with addition of high concentrations of BA. Similar results was recorded by Peixoto et al., (2006) in Lippia junelliana. 
Table 2: The effect of different concentrations of (BA) on shoot formation of Aloysia citrolodora.

\begin{tabular}{lccc}
\hline Treatments & Shoot number/explant & Shoot length & Leaves number/shoot \\
\hline MS control & 1.32 & 9.23 & 10.41 \\
$\mathbf{0 . 4} \mathbf{~ m g / L ~ B A ~}$ & 2.74 & 10.52 & 12.21 \\
$\mathbf{0 . 8} \mathbf{~ m g} / \mathbf{L}$ BA & 3.63 & 10.74 & 12.37 \\
$\mathbf{1 . 6} \mathbf{~ m g} / \mathbf{L}$ BA & 2.98 & 11.80 & 12.75 \\
$\mathbf{3 . 2} \mathbf{~ m g / L ~ B A ~}$ & 4.5 & 12.7 & 14.0 \\
L.S.D 5\% & 0.54 & 0.22 & 0.96 \\
\hline
\end{tabular}

\section{Root formation:}

Individual shoots which were excised after 4 weeks from culturing on shoot formation medium was cultured on MS medium with different concentration of IBA $(0.5-2.0 \mathrm{mg} / \mathrm{L})$ plus $1.0 \mathrm{~g} / \mathrm{L}$ A.C. The $0.5 \mathrm{mg} / \mathrm{L} \mathrm{IBA}+1.0 \mathrm{~g} / \mathrm{L}$ A.C gave the highest average of root number (5.8 per shoot), also highest root length $4.9 \mathrm{~cm}$ and highest rooting percentage $95.9 \%$ as shown in table (3) and fig (2).

Table 3: The effect of different concentrations of (IBA) on root formation of Aloysia citrolodora.

\begin{tabular}{lccc}
\hline Treatments & Root number/explant & Root length $(\mathbf{c m})$ & Rooting \% \\
\hline (MS control) & 0.0 & 0.0 & 0.0 \\
$\mathbf{0 . 5} \mathbf{~ m g / L ~ I B A + 1 . 0 ~ g / L ~ A . C ~}$ & 5.8 & 4.9 & $95.9 \%$ \\
$\mathbf{1 . 0} \mathbf{~ m g / L ~ I B A + 1 . 0 ~ g / L ~ A . C ~}$ & 4.6 & 3.75 & $90 \%$ \\
$\mathbf{2 . 0} \mathbf{~ m g / L ~ I B A + 1 . 0 ~ g / L ~ A . C ~}$ & 3.7 & 3.00 & $75 \%$ \\
L.S.D 5\% & 0.71 & 0.42 & \\
\hline
\end{tabular}

The estimation of root formation percentage of lemon shoots culture was affected by IBA showed that the lowest levels of auxin $(0.5 \mathrm{mg} / \mathrm{L}$ IBA $)$ gave a rise of rooting percentage reached to $95.9 \%$ of root formation. Increasing the levels from auxin decreased the parameters of root number and root length IBA. These result in agreement with those of El-Zeiny et al., (2013) they noted that IBA is most often recommended auxin as a rooting agent because it less phytotoxic, over a broader range of concentrations and active. IBA was significantly more stable than IAA to autoclaving, so the majority of IAA could be degraded under the same concentration.

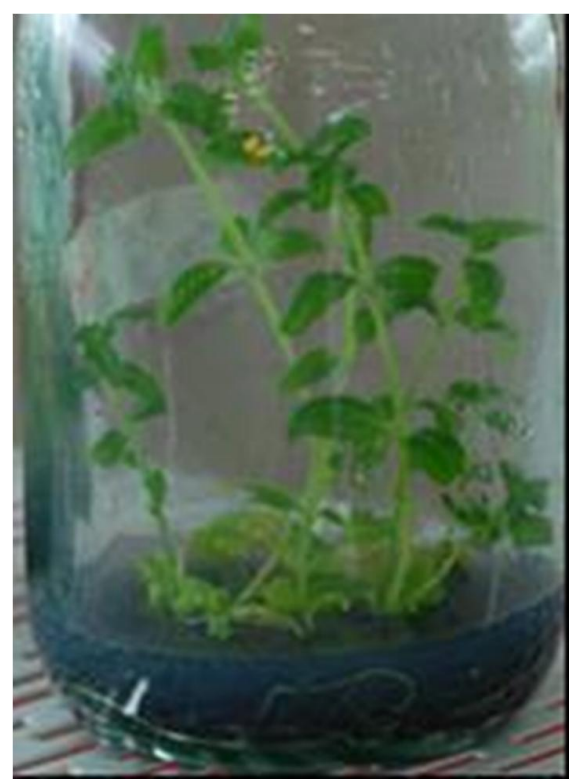

Fig. 2: Root formation on MS medium $+0.5 \mathrm{mg} / \mathrm{lBA}+1.0 \mathrm{~g} / \mathrm{L}$ A.C

\section{Acclimatization:}

Data in fig (3) reported that media contained peat moss: vermiculite $(1: 1)$ gave the highest transplants survival percentage $(91 \%)$. Followed in descending order by peat moss + vermiculite + washed sand (1:1:1) gave (75\%) and peat moss + washed sand (1:1) which recorded the lowest result 
(55\%). Papafotiou et al. (2017) showed an 83\% survival rate of resulted plantlet after acclimatization in a mixture of peat moss: perlite (1:1), these result in agreement with Oladzad et al. (2012), they found that a high acclimatization rate of survival percentage was achieved on a composing soil mixture from vermiculite, perlite and soil.
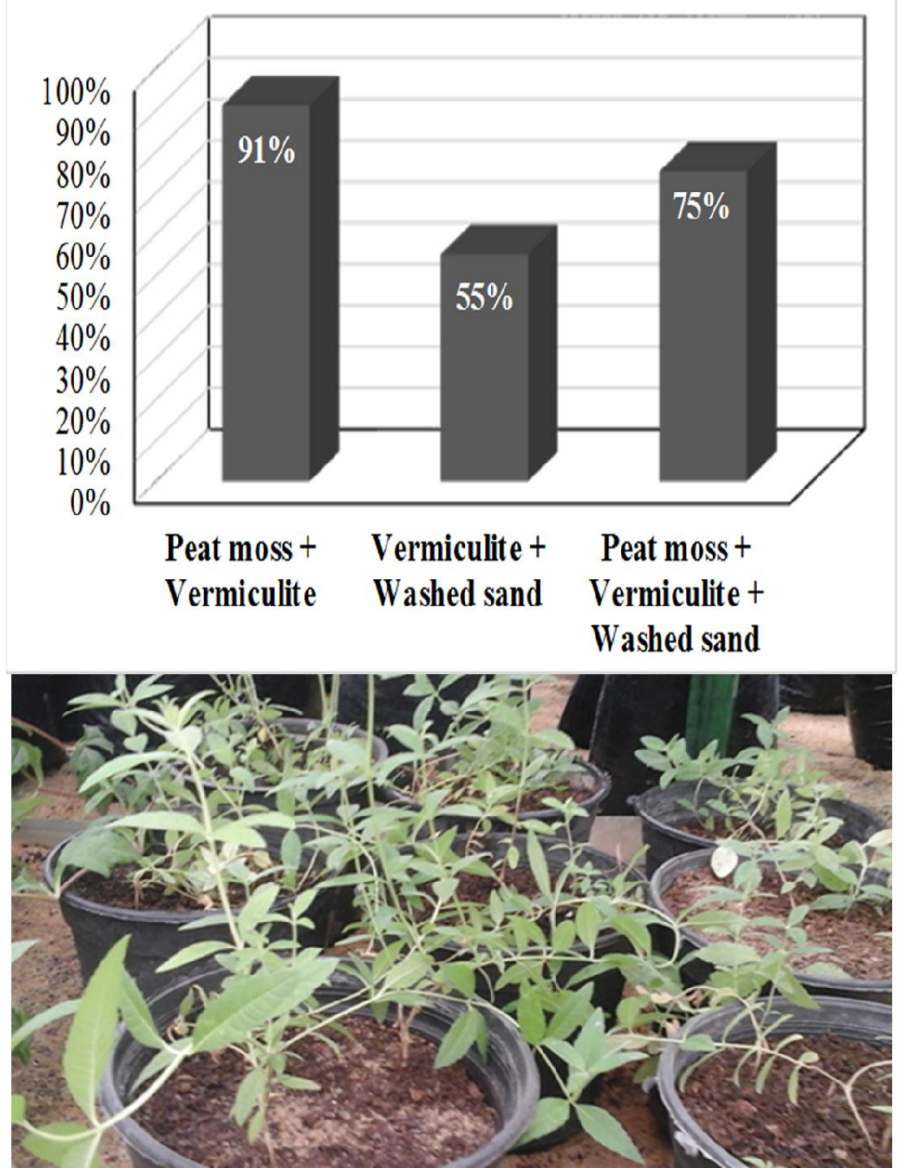

Fig. 3: Effect of medium mixture on survival percentage (\%) of Lemon verbena plantlets.

\section{References}

Akeroyd, J.R., 2000. Aloysia. in European garden flora, 6: 153

Ali, H.F., H.S. El-Beltagi and N.F. Nasr, 2011. Evaluation of antioxidant and antimicrobial activity of Aloysia triphylla. Electronic Journal of Environmental, Agricultural \& Food Chemistry, 10(8).

Beemnet, M., B. Wondu, and A. Solomon, 2013. Performance of Lemon Verbena (Aloysia triphylla L.) for Morphological, Economic and Chemical Traits in Ethiopia. Am. Eurasian J. Agric. Environ. Sci., 13 (11): 1576-1581.

Cabanillas, C.M., M.L. Lopez, G. Daniele, and J.A. Zygadlo, 2003. Essential oil composition of Aloysia polystachya (Griseb.) Moldenk under rust disease. Flav. Frag. J., 18: 446 - 448.

Dahab, A.M., M.A. Habib, Y.A. Hosni and A.M.M. Gabr, 2005. Effect of MS-salt strength, sucrose and IBA concentration and acclimatization media on Ruscus hypoglossum L. micropropagation. Arab J. Biotech, 8: 141-154.

El-Banna, H., 2018. In vitro Callus Induction and Plant Regeneration of Aloysia triphylla, a High Value Aromatic and Medicinal Plant. Journal of Plant Production, 9(3), 281-288.

El-Zeiny, O.A.H., U.A. El-Behairy, G. Zocchi and M.M. Rashwan, 2013. Commercial production of globe artichoke (Cynara scolymus L.) in vitro. Egypt J. Agric. Res., 91(3): 933-1007. 
Figueiredo, R.O.D., M.B. Stefananin, I. Ming, M.O. Marques, and R. Facnali, 2004. Essential oil composition of Aloysia polystachya Herit Britton leaves cultivated in Botucatu, Sao Paulo, Brazil, Acta Horticulture, 629: 131 - 134.

Hanna, F.M.A., H.S. El-Beltagi, and N.F. Nasr, 2011. Evaluation of Antioxidant and Antimicrobial Activity of Aloysia triphylla. Electronic J. Environ Agric. Food Chem., 10(8):2689-2699.

Lloyd, G.B. and B.H. McCown, 1980. Commercially feasibl micropropagation of mountain laurel (Kalmia latifolia) by use of shoot tip culture. Proceedings of the International Plant Propagators'Society, 30: 421-437.

Murashige, T. and F. Skoog, 1962. A revised medium for rapid growth and bioassays with tobacco tissue culture. Physiol. plant, 15: 473-479.

Oladzad, A., A. Qaderi, H. Naghdi Badi, and A.R. Zare, 2012. Rapid micropropagation of lemon verbena (Lippia citriodora L.) using in vitro culture. Journal of Medicinal Plants, 2(42): 145-153.

Papafotiou, M., A.N. Martini, and G. Vlachou, 2017. In vitro propagation as a tool to enhance the use of native ornamentals in archaeological sites of Greece. Acta Horticulturae, (1155):301308.

Peixoto, P., F. Salimena, M. Santos, L. Garcia, P. Pierre, L. Viccini, and W. Otoni, 2006. In vitro propagation of endangered Lippia filifolia Mart. and Schauer ex Schauer. In Vitro Cell. Dev. Biol. Plant, 42:558-561

Rezig, L., M. Sadaa, N. Trabelsi, S. Tammar, H. Limam, I.B. Rebey, A. Smaoui, G. Sghaier, G. Del Re, R. Ksouri, and K. Msaada, 2019. Chemical composition, antioxidant and antimicrobial activities of Aloysia citridora L. essential oils and methanolic extract. Italian Journal of Food Science, 31(3).

Sharaf El-Din, M.N., O.M. El-Kafie, H.A. Ahmed, and H.Y. El-Banna, 2011. Tissue culture propagation of lemon verbena (Aloysia citridora). J. Plant Production, 2(6): 823- 835.

Snedicor, G.W., and W.G. Cochran, 1980. Statistical Methods. Sixth. Edition, Iowa State Univ. Press, Amer., Iowa. USA Swartz. 